\title{
Transformation of Political Communication Functions in the Regional Political Process (Evidence from the Tyumen Oblast)
}

\author{
Galina Gerasimova ${ }^{1}$, Olga Shvetsova ${ }^{1} \&$ Lamara Mehrishvili $^{2}$ \\ ${ }^{1}$ Department of Marketing and Public Administration, Industrial University of Tyumen, Tyumen, Russian Federation \\ ${ }^{2}$ Department of Humanities and Technologies, Industrial University of Tyumen, Tyumen, Russian Federation \\ Correspondence: Galina Gerasimova, Department of Marketing and Public Administration, Industrial University of \\ Tyumen, Tyumen, 625000, Russian Federation, e-mail: ggerasimova6609@nanyang-uni.com
}

Received: September 14, 2021

Accepted: October 7, 2021

Online Published: October 21, 2021

doi:10.11114/smc.v9i2.5387

URL: https://doi.org/10.11114/smc.v9i2.5387

\begin{abstract}
The relevance of the policy areas reflected in this scientific article stems from the essential and peculiar fact that the entire international community increases interest in political communication because of its functionality and flexibility. The transformation of communication functions of a political nature considered within the constituent entities of the Russian Federation is vital for each of the spheres of State administration. It is the multifaceted nature of the topic that determines its importance in both academic and policy circles. A literate and intensive study of the development of political communication makes it possible to conclude the multifaceted influence of the historical era on the political structure of both the country as a whole and the subjects in particular. This aspect shows the diversity of communication functions in the State's political life and the likelihood of their lasting transformation. This article aims to give qualitative consideration to the various functions of political communication, using the example of the Tyumen region as an essential subject of the Russian Federation. The primary method of investigation of this problem was the analysis of scientific works of leading political scientists, philosophers and sociologists. Thanks to these works, the authors were able to trace the relationship between an era, type of the State, its social orientation and the development of political communication functions in terms of regional forms. The functions of political communication in the regional process of the Tyumen Oblast are directly dependent on institutional and functional groups and lobby associations, which are common in all regions. Knowing the dependency of functions on the well-defined aspects of political organization in an article helps to predict, or at least track, the likelihood of new functional diversity in political communication and steer it in the right direction.
\end{abstract}

Keywords: regional interaction, public administration, mass media, subjects of the social level

\section{Introduction}

In the last century of political system development, scientists increasingly question the interaction between political subjects and their communication effectiveness. Political communication is a special network of interaction in the information field of politically active actors and dialogue between them within the framework of the acquisition and control of power, management relations in a limited circle of society (Kaminskaya, 2020). Political communication and the multifaceted interaction of different objects of political science is a multidimensional and somewhat controversial process. As a system, political communication consists of 9 elements: political actors, organizations of investigation of audiences, audiences, organizations dissemination the content of political communication, organizations ensuring dissemination of the content, organizations regulating the process of political communication, organizations controlling this process, and organizations providing storage of political information (Grishin, 2012). With the development of political science, the connotation of its terms and various communication relationships developed as well. The media were playing an increasingly important role and had changed significantly under the influence of globalization. Their significance is hard to overestimate as they are the main actors disseminating information of any kind (Upornikova, 2018). There are many possible ways of the media can impact the political process. R. Hague (2016) emphasise four different mechanisms for media influencing politics: reinforcement, agenda-setting, framing and priming. Many analyses of the relationship between media and democratic politics reach broadly the same conclusions and an example is James Curran`s excellent analysis of media and democracy (Curran, 2011). In the modern world, much attention is 
paid to the development of online mass media and their influence on political processes and public policy. The most important groups with regional rhetoric are the constituent entities of the Russian Federation, represented by the regions, autonomous regions, autonomous okrugs, republics, regions, and cities of federal significance. The heads of these administrative units bear the most significant responsibility in regional policy. The most important things for future development are happening between mayors, city heads, and governors. That is why the authors carry out this study on the example of the Tyumen region as a subject of the Russian Federation.

Another essential and integral group involved in political communication is subjects of the social level. They include such units: classes, ethnos, groups, individuals, bourgeoisie, working-class, national groups, and many others. Subjects belonging to another level of the political aspect - the institutional one - also play a significant role. The most common are the State itself, its parties, trade unions, universities, schools, etc. There are also functional subjects, such as the army, various lobbies, transnational corporations, and churches. One of the largest and most successful trade unions, the Tyumen Interregional Union of Trade Union Organizations, is currently operating in the Tyumen Oblast. The higher authorities in the form of the city and Oblast Duma and administration listen and turn for advice to the socially and politically active citizens of this association.

Joining trade unions is the simplest and most effective way to participate in modern political communication. Their political connection with the Tyumen authorities helps establish two-way communication between the "elite" and the "counter elite". The political party is a more modernized and developed instrument for political discourse. Regional branches of such leading parties, as the Liberal Democratic Party of Russia (LDPR), the Communist Party of the Russian Federation (CPRF), and United Russia are registered in Tyumen. Among them, there are also less prevalent parties based on party elections held recently: "Patriots of Russia", "Party for Justice", "Party of People's Freedom", etc. Due to such a wide range of impact schemes, political communication functions become flexible and always ready to adapt to the system (Pozdnyakova, 2019). The examination of the main functions in the political world, which are inherent in the first place to State structures, is a vital and fundamental part of the study. Thus, the regulatory and information function creates the foundation of all policy and its interaction with subjects (Stychkov, 2017). With the development of the State, other political layers, so-called pressure groups, have become increasingly important. These include political parties, political movements, trade unions, and the lobby. Looking at how much their role is changing, it is possible to say that it is within their existence that the modern political reality emerges (Nazarov, 2020).

\section{Materials and Methods}

The study was based mainly on theoretical writings by authoritative scholars who, through qualitative analysis, presented knowledge of political communication in the most structured way possible. Also, the process of reformation of discussions between different bodies of regions and federation was monitored. This made it possible to identify as precisely as possible the reasons for the change in the functions of communication, their development, and the shifting of focus concerning the political stage of development of the State.

Among the researched works are the studies of such scientists as: T. Kaminskaya (2020), M. Grachev (2020), K. Schuhmann (2018) D. Kiran (2018), etc. Their contribution to the development of political science made it possible to analyse the transformation of the function of all political communication as a vast stratum of society. The authors considered the works from the perspective of contemporary research, based on the classic examples of these researchers. The works of K. Schuhmann (2018) and T. Kaminskaya (2020) were studied. They made it possible to competently inscribe all the fundamental principles of building society and its dialogue with the elite strata into the modern picture of the world. Through this part of the study, the authors have identified the main functions of modern political communication, which can vary depending on the interpretation of individual scientists. These functions include dissemination of ideological and political values, knowledge about politics, political information; integration and regulation of political relations; development of public (political) opinion; propagation of political culture, its development among individuals; political and cultural exchange; preparation of the public for participation in politics.

Since the purpose of the study was to examine the various functions of political communication qualitatively, it was essential to read scientific works intended to review each function individually. Since the change of these functions appears in the creating history for the present study, authors tool the works of different periods relevant to the subject matter. The research was carried out based on the Tyumen oblast, which is a collective image of all the constituent entities of the Russian Federation. Therefore, the main criterion in this area was to choose the most critical bodies of communication. Thus, the authors analysed the local media, their political agenda, and the federal centre's contradictions. Various information portals have become the primary sources in this field. Within the framework of the online publications in Tyumen and Tyumen Oblast, the most relevant news on the public and political agenda is published. The information flows from articles, interviews, news, and other forms of news journalism. In addition to the 
media, the study examines the region's administrative units, including the Governor's Advisory Council and the Administration (Leiserson, 2020; Romeu \& Alvarez, 2019).

Also, as a subject of communication, the work considers parties, political movements, trade unions. According to the results, they play a critical role in this contact. The structure and ambiguity of lobbying and pressure groups expanded the field of study as well. The quality of communication, its ideological orientation, and the objectives pursued vary depending on which subject influences the dialogue with the centre. This comprehensive study of the various elements of political communication makes it possible to see the reasons for the development and changes in the functions inherent in the political sphere more clearly.

\section{Results}

According to the study, successful political rhetoric depends on the quantity and quality of the knowledge of its participants in the period of its implementation and the readiness of such bodies as the State and the party apparatus to implement it not in an only safe, but effective manner. Successful political communication is the most competent and effective way to hold or seize power in a situation of uneven or unstable direction. An essential outcome of the study was understanding the following factor: a State is the basis of any successful political communication. Moreover, having studied scientists' research, it is also worth noting the importance of a structural approach to activities such as politics. This is necessary due to the variability of this sphere and its constant movement. To prevent the world from plunging into chaos, there is a way of conducting a policy that includes enlightened political communication, transformed by the development of the State and social relations in general. Through active interaction with citizens of the country and organizations, leadership control and a general partnership with a more successful member are achieved. Since political communication is an instrument of power, its structure also has an internal institutional dimension, which in the future can be described in accordance with progressive communication policies. This is the primary value of the study - the ability to anticipate the probability of developing already existing functions or creating new ones (Esser et al., 2018).

For all represented subjects, political engagement can provide both a way to address a given issue and debate within different groups. Thus, the regional heads decide which facilities are needed in a given city or in which budget of the state should be invested. Therefore, regional agencies' policy rhetoric is so vital for understanding and communicating the overall political system. The work considers this aspect in the case of the Tyumen Oblast, which comprises important State Districts such as the Khanty-Mansi Autonomous Okrug - Yugra and the Yamalo-Nenets Autonomous Okrug. One of the most critical and influential channels for successful and high-quality political rhetoric is, of course, the media. As a matter of public policy, these are directly national newspapers, channels, radio stations, and websites. This type of receiving, processing, and transmitting information originated with the birth of the State. With the evolution of the social and political system, the components of the media have also changed. Since each public and partly commercial facility has its well-structured press service whose purpose is to disseminate information to various sectors and groups of society, it is now possible to obtain information from a verified source. Thus, there is a relatively wide range of different media in the Tyumen Oblast. It can be found in newspapers, magazines, tabloids, radio stations, and television stations. The main reliable source in this field is news publications of state character published for each entity separately. Thus, in Tyumen, news magazines post all-important political changes or events on their portal.

It is essential to note the incredible dynamics of the development of ways to convey information. In 10 years, no one has seen the radio station as an authoritative source, whether for political discourse or mere narrative. The Internet governed the modern world, and information education focused on websites, communities, and social networks. A major breakthrough in political communication at the network community level is feedback, which leads to informed dialogue. The field of information technology is growing and developing in correlation with the development and growth of the State system. The more modernised the political communication in the country, the more sources of reflection and direction it can be in the media. Thus, the difference between the past and present communications media became apparent (Gil de Zúñiga and Chen, 2019).

The Tyumen Oblast is an excellent example of the separation of political structures. If the official head is the mayor of the Oblast, Alexander Viktorovich Moor, who together with his cabinet and administration represents the elite; the counter elite, in this case, are those who disagree with some decisions taken at the regional level. For example, journalists organize hunger strikes when they are not allowed to perform their work fully. This is the answer to the communication that never happened. The most accessible and understandable communication between the population of Russia and its direct head is "Direct Line with the President", often called by the inhabitants of the Tyumen Oblast. This factor indicates the limited development of the political system due to the specific features of the State. As with all pillars of the State, the political process, which includes direct communication, has several grouped subjects whose list opens up the horizons of how they affect political life. 
Social subjects are an essential and integral group in political communication. These include classes, ethnos, groups, individuals, the bourgeoisie, the working class, national groups, and many other entities. Subjects belonging to another level of the political aspect - the institutional one - also play a significant role. They all have different credibility, but to exclude someone is to reject part of a natural political process. Unlike, for example, the latter group has no vested interest in seizing power. It is often "dragged" into political discourse in connection with the desire to gain credibility, sponsor, or exercise their inherent professional activity. Interest groups are an invisible bridge between public opinion and the highest authority of the State. This is the case of societies of people who come together voluntarily or under duress to represent a particular social or political group. These associations are often called lobbyists. The term is now firmly embedded in the political rhetoric of all countries, including the Russian Federation and its constituents. Although many political scientists believe that lobby groups are an invisible part of corruption, placing private priorities above national priorities, it is through them that various commercial funds exist. There are many such communities in the political sphere, and they have a considerable influence on the entire political process. The main functions of these associations are articulation of interests, information sharing, aggregation of interests, development of political elites.

The most common and affordable way to accumulate people into represented groups is to form trade unions. Joining trade unions is the simplest and most effective way to participate in modern political communication. Their political connection with the Tyumen authorities helps establish two-way communication between the "elite" and the "counter elite". The political party is a more modernized and developed instrument for political discourse. The same applies to the privileges of lobbying groups. They also include large organizations that invest their income in the country's capital; foundations, movements, and other types of political, economic, and social associations. Due to their many levers of influence, their contribution to political communication is immense. Their position in the hierarchy of effectiveness of political rhetoric both in the Tyumen Oblast and in other RF entities is indisputable and justified. With each passing year, the importance of lobby groups will only increase and completely transform political communication. With the development of the modern world, the foundation of which was born on the economic success and progression of the power of capitalism, the financial sector becomes the most authoritative both in politics and in the public sphere (Marczak, 2020).

In terms of regional attempts to adapt to transformation, the primary indicator is international conferences, which are often held online in today's world. Thus, in summer 2021, there will be various conferences in Tyumen. Interested citizens of other States would join the areas under discussion, such as public life and the army, which was part of political life. The region admits students, schoolchildren, media representatives, and anyone who can contribute to the debate. Ten years ago, humanity could not have imagined how much the availability of online platforms would transform the entire political, economic, social, and scientific debate. This is a breakthrough and a qualitative adaptation of the political system to new factors that come from outside for various reasons. Another essential feature is the active inclusion of important issues and developments of the younger generation in the debate. In a modern and free-thinking world, everyone has every right to express personal opinion among the leaders of the State. This factor represents a proactive change in discourse thanks to the system itself. The infiltration took place from within when the leading authorities decided to change an unnecessarily closed sphere. From these examples, it is clear that there has been a qualitative change in the political communication functions of the regional political process, such as the regulatory and, of course, reactive function.

\section{Discussion}

The topic of political communication between actors of state influence, to which this article is devoted, began to interest scientists long before the birth of a stable political state in its modern sense. In any case, sociologists of past centuries have wondered about the relationships between different groups in society, their motivations, and the processes that emerge after making compromises or receiving reactions. There are some contradictions in the theories of the origin of peace. And, as known, they will develop in a certain way. Through extensive research from various sources, it could be stated that after conflicts and disagreements, change always comes. But the main purpose of this study is to analyze the qualitative and positive changes that have shifted the communication between political actors towards a more modernized and progressive impact. The functions studied in this article originated from the most ordinary desires, and it was only over time that they became a whole system.

The study to which this article refers would not have been possible had it not been for the writings of researchers who have been monitoring the development of the political communication function and the political process sector as a whole. Considering that the political sphere develops directly with the State, it was essential to go back to the origins and find the cause of the emergence of political science as a science. Massive research of Russian and world scientists provided general information about the structure of the State. They detailed the process of State creation and its gradual development. Thus, the system of State organization in the Council has changed from a clerical system to a secular one, allowing politics to penetrate ordinary people's lives gradually. Political scientists are now interested in Russia, which changed by following the example of Western countries. It was only after the country's division into administrative 
units and the transfer of certain autonomy in the decisions that this study became possible since its main subject is the Tyumen Oblast (Fisher, 2018; Lu, 2018).

The paper used both classic examples of their analysis and modern rethinking of certain aspects. T. Kaminskaya (2020) explored the ideas of Walter Lipman, who made the first studies of the interaction of groups in society, as well as the diversity of subjects and objects in science dialogues. This researcher is best known for introducing the term "stereotype" into natural language. In this respect, it is essential to note that political science and all its fields extend the sciences of philosophy and psychology. Therefore, the first thoughts of W. Lippmann play a vital role in the study. It is here that the informative function of political communication begins to emerge. The world is expanding and opening from different sides. The views of this researcher transformed into the political paradigm of T. Kaminskaya (2020), who drew a qualitative parallel between sociological and political functions. In her opinion, sociological sciences differ only in what narrow field is sociology, political science, or psychology. If you look at the diversity of these sciences, you can understand that they are all a single paradigm of the structure of society. Therefore, according to Kaminskaya, it is essential not to limit knowledge to one sphere only, but to try to see as much as possible around. To reinforce her view, T. Kaminskaya devoted her scientific study to the works of W. Lippmann, as he was the first to notice the similarity of different branches of science and the limitations of science to only one sphere. The parallel drawn by the scientist fits the study perfectly. Political communication functions do not change only after major political upheavals or reform changes. They can progress from the development of absolutely all spheres of society.

Suppose you look a little bit more deeply at the ideas of W. Lippmann. In that case, you can understand that this person started to develop his thought not only in the realm of the state-society but also in such relations as the state-companies, the state-brokers, state-journalists, etc. Based on a broader world view, W. Lippmann contributed to the emergence of public relations science and thus broadened the horizons of social interaction. Russian researchers made an important contribution to the development of political sciences. Thus, according to M. Grachev (2020), the term "political communication" came into use after World War II, when all countries had to communicate with each other most strongly and stably. This function could be called unifying or connecting. This layer of communication makes it possible to speak of a convergence of views between different political groups, not only in the regions of one country but throughout the world as a whole. This principle lays down ideology in political groups. It is important to note how strong the international situation is for all countries, but the overall problem in the State for all regions is equally critical. The classical postulates of the 16th century proved relevant to modern research. Thus, in his critical article, K. Schuhmann (2018) managed to adopt "Leviathan" by Thomas Hobbes to the modern world. According to a slightly softened view of Thomas Hobbes theory, represented by "war of all against all" and propagating that country's natural state is anarchy, there is always a struggle for power in the world. This is a natural state of affairs for rival parties or candidates for one position.

In studying this field, it is impossible to do without a qualitative analysis of works written by such leading authors as American political scientist A. Bentley and Italian sociologist V. Pareto. It is their idea to create such concepts in world political science and sociology as "elite" and "counter elite". American scientist D. Kiran considered this political theory primarily in terms of management. Due to the difference in scientific detail, D. Kiran provided an interesting view of political elites. Like Bentley and Pareto, the researcher talks about how vital connecting political elites and counter elites are. His theory stems from the following: if there is no communication between the federal centre and various political actors, all regions will suffer. Thus, all economic moans, management, business, and other spheres are dependent on the correct implementation of public policies (Kiran, 2018).

As a rule, the State is an elite in the philosophical sense. Counter elites are the opposition strata of society. These two polar social layers will become the symbol of the driving force of the entire political process. During the development of their theory, researchers have come to distinguish a particular and rather specific unit - "Interest groups". This could demonstrate to society that every political leader, represented by a group of people, has unflinching or complex interests. Such perspective provided the proletariat with a metaphorical door to real politics, where only the bourgeoisie was previously. This creates contradictions in standard communication and new functional nuances. This idea is perfectly suited to the study of the political communication of the modern world, as it represents a turning point in the interaction of elites and counter elites. The American political scientist and philosopher Arthur Bentley wrote in his book that the whole political process is governed not so much by the State as by groups of interests that, through their involvement, can quickly and actively monitor conflict zones. A. Fontan (2021) studied this feature in his works. Through such changes, the authorities of a country can react quickly to the outbreak of any political, social, or economic conflict. For the first time, the fourth President of the United States, James Madison, used the political connotation of lobbyism to explain it as a special activity that influences international associations or even organizations with the help of various individuals. I. Upornikova (2018) analyzed This opinion in her works. Lobbying plays a vital role, despite the non-state basis of development. These particular subjects can significantly affect the overall political situation under certain circumstances, giving them a substantial advantage in the political process. 
The idea of American political scientist David Easton is critical in understanding the political system in general and its communications in particular. Having written many articles about D. Easton, H. Bang (2021) explained it in detail in his work. Thus, he introduced a more modern view of a somewhat irrelevant theory. According to $\mathrm{H}$. Bang, the understanding of the system, described below, remains equal to the modified political organism of the State to this day.

The works of D. Easton, on which H. Bang (2021) relies, reflect the following idea: the political system as an essential sphere of state functioning, is absolutely open and represents a vulnerable organism for the "peremptory impact" of its environment. This environment can include several social constructs, institutions and economic shocks, and distant art and culture in a primitive sense. Thus, D. Easton believed that the political system was always skilfully governed by the innovations brought about by the environment, trying to incorporate all changes into its framework immediately, optimize them. D. Easton called all the interactions between the new introductory and the system itself as nothing more than "exchanges" and "transactions", logically leading to relations in the law of "input-output". Thus, the former included all the existing system requirements and its sound support in its implementation, and the latter all the consequences in the form of direct decisions and actions. The most crucial element that arises in this political mosaic is the so-called "feedback loop". This element determines the effectiveness and efficiency of everything that happens, from which the new one will take root in the political sphere or die. If the innovation became too revolutionary and progressive, it could lead to the collapse of the entire system, however flexible it might be. Although this theory dates back to the 1960s, its foundations are still valid today. Political communication is changing rapidly and adapting as quickly as possible. If there were political conferences exclusively for scientists and politicians 10 years ago, more and more interested sections of the population are accepting bureaucratic decisions nowadays. Thus, thanks to modern participation formats, the political debate is not only open to people from a particular region, but also to world thinkers. This significantly expands the political discourse, signalling the irreversible transformation of this sphere.

It is, of course, important to take into account not only the scope of information sources but also the constraints that the public system imposes on public activities. The Constitution, strictly defined legislative system's framework, and standard-setting activities in the Russian Federation may contain such limitations. As a constituent entity of the Russian Federation, the Tyumen Oblast and its political communication must fall within the strictly defined framework of State broadcasting. This political process will be a complex and intricate system, changing from year to year in response to the natural transformation of the world. The study was carried out as part of a study of the Russian Federation's constituent entity, which limits it regionally.

\section{Conclusion}

The authors provided a qualitative study of the functions of political communication and their variability and successfully fulfilled the purpose of the work. As a region actively interacting with various actors of the political process, the Tyumen Oblast uses a complete set of tools for successful communication. This subject illustrates how the system of interaction between the Federal Centre and its regions is currently functioning. In the scientific literature, the authors have concluded that the change in the functions of political communication depends on the degree of development of the State itself and its openness to dialogue.

From the theoretical point of view, certain conclusions can help monitor changes in different structures of functional diversity of political interaction. Thus, the change in the format and functions of political communication, both in respect of such a region as the Tyumen region and the State as a whole, is a natural process of development. Looking back at how the organs of the State interact with each other, the authors were able to see how political communication is linked to the era in which it takes place. The more rapidly and effectively a political society develops, the more successful and liberal political communication within it will be. The information function of political communication spread to the entire population of the country and politically active objects of the regions. The regulatory function has begun to give more freedom to regions and other subjects.

In the course of the study, not only the importance of the functions of political discourse but also the degree of gradation of the actors themselves became clear. The development of this process' forms and functions depends on which organs are a system of interaction. Since the political sphere is very vulnerable and constantly changing, the subjects carry more specific features. Trade unions and political movements of the Tyumen Oblast are excellent examples of this. The response function has now become as developed as possible in the political system. Because of the rapid monitoring of grievances or the likelihood of conflict, there are no significant radical opposition forces in the Tyumen Oblast or elsewhere. The regional dimension also makes a significant contribution to the entire rhetoric of the political process. Using the example of the Tyumen Oblast, the authors are convinced that the constituent entities of the Russian Federation have many levers of pressure on the general political situation and are full participants in political communication at this stage of the development of the modern world. 


\section{References}

Bang, H. (2021). David Easton's postmodern images. Political Theory, 26(3), $281-316$. https://doi.org/10.1177/0090591798026003002

Curran, J. (2011) Media and democracy. London: Routledge. https://doi.org/10.4324/9780203406878

Esser, F., Aalberg, T., Reinemann, C., \& Stanyer, J. (2018). Populism as an expression of political communication content and style: A new perspective. The International Journal of Press/Politics, 23(4), 423-438. https://doi.org/10.1177/1940161218790035

Fisher, K. (2018). What is meant by 'trust' in news media? In Trust in Media and Journalism. Empirical perspectives on ethics, norms, impacts and populism in Europe (pp. 19-38). Wiesbaden: Springer Fachmedien Wiesbaden. https://doi.org/10.1007/978-3-658-20765-6_2

Fontan, A., \& Altafini, C. (2021). A signed network perspective on the government formation process in parliamentary democracies. Scientific Reports, 11(1), article number 5134. https://doi.org/10.1038/s41598-021-84147-3

Gil de Zúñiga, H., \& Chen, H. T. (2019). Digital media and politics: Effects of the great information and communication divides. Journal of Broadcasting and Electronic Media, 63(3), 365-373. https://doi.org/10.1080/08838151.2019.1662019

Grachev, M. N. (2020). The concept of the "truth decay" in a digital society (an analytical review). Outlines of Global Transformations: Politics, Economics, Law, 13(2), 229-248. https://doi.org/10.23932/2542-0240-2020-13-2-12

Grishin, S. E. (2012). Political communication. Saratov: Slovo Publishing House.

Hague, R., Harrop M., \& McCormick J. (2016). Comparing government and politics. Comparing Government and Politics, 90-107. https://doi.org/10.1007/978-1-137-52838-4_6

Kaminskaya, T. L. (2020). New trends in Russian political communication. Political Linguistics, 6(84), $112-134$. https://doi.org/10.26170/pl20-06-01

Kiran, D. (2018). Seven traditional tools of TQM. Total quality management. New York: Ardis Publishing. https://doi.org/10.1016/B978-0-12-811035-5.00020-9

Leiserson, A (2020). Problems of methodology in political research. Political Science Quarterly, 68(4), $558-584$. https://doi.org/10.2307/2145190

Lu, X. (2018). From "ideological enemies" to "strategic partners. A rhetorical analysis of U.S. - China relations in intercultural contexts. Howard Journal of Communications, 22(4), 336-357. https://doi.org/10.1080/10646175.2011.617163

Marczak, M., Rochester, J., Bailey, T., Gansen, J., Zapata, A., Kosobuski, L., ... Olson, P. (2021). When government gets it right: How a strategic visioning process aligned nested government systems to champion local relevance and determination. Interdisciplinary Journal of Partnership Studies, 7(2), article number 7. https://doi.org/10.24926/ijps.v7i2.3477

Nazarov, M. M. (2020). Political communication in post-truth society: Citizens and trust in information sources. Power, 28(1), 105-114.

Pozdnyakova, V. V. (2019). The concept and essence of political communication. Young Scientist, 35(273), 58-69.

Romeu, V., \& Alvarez M. (2019). Communication, socialization and citizenship: Theoretical-conceptual bases to understand the expression of contemporary citizen politics. Studies in Media and Communication, 7(2), 9-19. https://doi.org/10.11114/smc.v7i2.4428

Schuhmann, K. (2018). Thomas, Hobbes Leviathan. London: Bloomsbury Publishing.

Stychkov, I. K. (2017). The concept of the public sphere by J. Habermas: the value of information for democracy. In Advanced Information Technologies: Proceedings of the International Scientific and Technical Conference (pp. 16-27). Samara: Samara University.

Upornikova, I. V. (2018). The genesis of the forms of political communication. Philosophy of Law, 4(87), 19-29.

\section{Copyrights}

Copyright for this article is retained by the author(s), with first publication rights granted to the journal.

This is an open-access article distributed under the terms and conditions of the Creative Commons Attribution license which permits unrestricted use, distribution, and reproduction in any medium, provided the original work is properly cited. 